\title{
Study on the Development Dilemma and Strategies of Small and Medium Enterprises in the New Period
}

\author{
Hong $\mathrm{Ji}^{1, \mathrm{a}}$, Haiyan Yan ${ }^{2, \mathrm{~b}}$ \\ ${ }^{1}$ Jiangxi Normal University Science and Technology College, China \\ 2 Jiangxi Normal University Business College, China \\ ajxsdjh@vip.sina.com, ${ }^{\text {b7 } 761426721 @ q q . c o m ~}$
}

Keywords: Small and medium enterprises; Development dilemma; Strategy orientation.

\begin{abstract}
Small and medium-sized enterprise is an important force in the national economy and social development. Its development is not only an important basis for the stable and rapid development of the national economy, but also affect the stability of people's livelihood and society. In recent years, although the environment of the development of small and medium-sized enterprises has been significantly improved, the development of the quality and level has greatly improved, but the inherent financing difficulties, the lack of adequate human resources, the low of technical improvement, still brings impact to the small and medium-sized enterprise's survival and development in the future. Based on the analysis of economic function and the utility , the basic characteristics in the new period, made clear the plight of the development of small and medium-sized enterprises in our country, then puts forward some strategies to promote the development of small and medium-sized enterprises in our country from broadening the financing channels, cultivating talent team, promoting the technology innovation, speeding up the transformation and upgrading strategy, etc.
\end{abstract}

\section{Introduction}

The division of SMEs (small and medium-sized enterprises) in our country adopts the quantitative criteria, and it is a composite volume standards, using employees, operating income, total assets and the type of industry where standards. The latest "SME Plan-type standard," put China's SMEs into three types of the medium, small and micro, which applies industries including agriculture, forestry, animal husbandry and fishery, industry (including mining, manufacturing, electricity, heat, gas and water production and supply), construction, wholesale trade, retail trade, transportation (excluding rail transport), warehousing, postal services, accommodation, catering, information transmission industry (including telecommunications, Internet and related services), software and information technology services, real estate development, property management, leasing and business services and other unlisted industries (including scientific research and technical services, water conservation, environment and public facilities management, resident services, repairs and other services, social work, culture, sports and entertainment, etc.). SMEs in China has become an important base power for the development of the socialist market economy and an important driving force for building a socialist harmonious society, plays an irreplaceable role in economic prosperity, increasing employment, promoting innovation, improving people's livelihood and other aspects.

\section{Economic Function and Utility of Small and Medium Sized Enterprises in the New Period}

Small and Medium Enterprises is an Important Force to Deal with the Impact of the International Financial Crisis. Compared with large enterprises, SMEs, especially micro-enterprises objectively have low labor costs, strong liquidity of production elements, "small boat U-turn" and other comparative advantages, which has a certain buffer action for the impact of the economic crisis . In the new period, small and medium enterprises have become the main body and foundation to deal with and expand the impact of the international financial crisis. The development of SMEs is an important part of coping with the international financial crisis and the objective 
requirements, also is conducive to further consolidate and expand the results of the impact of the international financial crisis and to maintain long-term stable and rapid economic development.

Small and Medium Enterprises is the Basic Power to Promote Economic Structure Optimization and Adjustment. On the one hand, small and medium enterprises is an important basis to speed up the adjustment of economic growth structure. Small and medium enterprises provide a lot of employment, increase the wage income for the majority of the people, is the main source of expanding domestic consumption demand, is also the main body in China's private investment and the important engine of economic growth. On the other hand, small and medium enterprises is an important basis to speed up the adjustment of the structure of urban and rural. Due to the uniqueness in factor endowment, history, tradition, culture and the level of economic development, county economy formed the regional market which any of the big companies are unable to cover and possess, formed the condition and foundation in the many small and medium enterprises to survive and develop. These small and medium enterprises are the important tax and financial resources to support the county economic growth, are also the main force of developing modern agriculture, building a new socialist countryside, and promoting the transfer of farmers, strengthening the county economy.

Small and Medium Enterprises is the Strategic Force to Promote Independent Innovation. Small and medium-sized enterprise has the original motive power and the strong innovation consciousness of independent innovation, is the main body of inputting the science and technology innovation and using all kinds of innovation results. The development of small and medium enterprises is conducive to accelerate the establishment of technological innovation system which take enterprise as the main body, the market as the guidance, combine with production and research, so that enterprises become the main body of research and development investment, technology innovation activities, and the application of innovative results. At the same time, the development of small and medium enterprises is also conducive to the growth of innovative talents, promote the strategic alliance of industry and research, play an important role in scientific and technological innovation of entrepreneurs and technology leader.

Small and Medium Enterprises are the Fundamental Force to Protect and Improve the Livelihood of the People. Ensuring and improving people's livelihood is the fundamental starting point and goal of accelerating the transformation of economic development mode. Small and medium enterprises is an effective way to eliminate social poverty, is also the main source of the life of the masses. Small and medium enterprises produce products or provide services, which usually relate with people's daily life or vital interests closely, especially the traditional manufacturing and wholesale and retail, accommodation and catering industry in small business, produce living necessities or provide convenient services for the majority of people, is the important force to promote market prosperity, to facilitate the people to live, to protect and improve the livelihood .

\section{Basic Features of China's Small and Medium Enterprises Development in the New Period}

Big Quantity, Small Scale, Region Difference. On the one hand, the number of small and medium-sized enterprises in China is large, and SMEs are widely distributed regardless of the township or the city . On the other hand, because of their small size and the existence of people, money and material constraints, it is difficult for small and medium enterprises to compete with some large enterprises. In addition, the development of SMEs in China is not balanced, the development of dominant region are more concentrated, especially in the Middle East with better economic situation, in which the number of small and medium enterprises, and the total output is significantly stronger than the western region.

Poor Organization, Mostly for the Domestic Market. As poor professional collaboration exist in the field of production, management system is not very perfect, and many other defects exist in its own organization structure and, which decide that a lot of small and medium enterprises are difficult to go out of the country, can only be for the domestic market. Although, some enterprises have expanded in recent years, but it is still difficult to adapt to the fierce competition in the international market. 
More Flexible Production, High Labor Intensity. The economic decision-making power of small and medium enterprises is highly concentrated, and the scale of enterprises is relatively small, which makes a lot of enterprises put their limited material resources, financial resources and human resources to the small market which are ignored by larger enterprises, so that it can better segment the market, the way of production is also more flexible. At the same time, China's small and medium enterprises are mainly distributed in some labor-intensive enterprises, their business investment elasticity and employment capacity are significantly higher than some of the domestic large enterprises.

\section{The Development Dilemma of Small and Medium Sized Enterprises in the New Period}

Although China has formulated a series of policies and measures to promote the development of small and medium enterprises, development conditions and environment has been significantly improved, the development of quality and level has been greatly improved, but the inherent structural adjustment difficult, financing difficulties, technical difficulties and facing the new problems about the high RMB exchange rate, lack of domestic demand,will continue to be intertwined ,superimposed on each other in the future development, then bring impact to small and medium-sized enterprises' survival and development.

Capital Shortage, Financing Difficulties. Enterprise development funds mainly come from their own accumulation and external financing. On the one hand, small and medium-sized enterprise is small, their own accumulation is relatively insufficient, resulting in a shortage of funds. On the other hand, in external financing, the existing financing methods and the financial system are not conducive to the financing of small and medium enterprises, its borrowing costs between five percent ten percent, even above four percent of SMEs' borrowing costs more than ten percent. Too high credit standards, cumbersome procedures set up many obstacles to the main financing channels for small and medium enterprises ${ }^{[1]}$.

Shortage of Human Resources. More than 70 percent of scientific research personnel are in Colleges and universities, scientific research institutes, Small and medium enterprises accounted for a small proportion, and there is a certain gap in the quality level of the same large enterprises. The low comprehensive quality of small and medium enterprise managers make it difficult to realize the scientific management system, which directly leads to the decline of enterprise management level, and the unhealthy development of enterprises. In addition, the low level of culture of general practitioners directly leads to the poor quality of enterprise products, the weak product innovation ability, can't realize the introduction of technological equipment successfully.

Weak Consciousness of Technological Innovation. Strengthening the independent innovation of enterprises is the key to enhance the core competitiveness of enterprises and to participate in market competition. Small and medium-sized enterprise need to have the power of technological innovation and internalize the inevitable requirement of enterprise internal development. This requires that enterprises have the urge of original innovation and the ability to introduction, digestion, absorption and re-innovation ${ }^{[2]}$. At present, the small and medium enterprises generally exist in the form of labor intensive industries, its process equipment fall behind, even with the low level of technology and rare patents. Due to the limitation of small and medium-sized enterprise scale, it is difficult to require them to invest a lot of money for technology innovation.

Facing Bottlenecks in Transformation and Upgrading. At present, China's economy has the industrial structure imbalance, lack of domestic demand and other deep-seated problems, in which it is difficult for SMEs' transformation and upgrading, and the process is slow. In particular, the three major industries of China's labor productivity growth has slowed down, the dependence of the industrial enterprises increased, reflecting the current the results of transformation and upgrading is not very significant ${ }^{[3]}$. At present, the transformation and upgrading of small and medium enterprises in China are faced with the following aspects: firstly, in the production and management, which still only looking for the competitive advantage of limited value in production costs and product prices, the strength of technology research and development is weak, the product technology content and added value is low. Secondly, in management, the lack of scientific management system of modern 
enterprise, effective management mechanism and scientific use of human mechanism, the problem of management confusion, power and responsibility, low efficiency is still widespread. Thirdly, in the technical equipment, there is a technical equipment aging, high pollution emissions, high loss, infrastructure supporting problems. Finally, the enterprise lacks the direction of transformation and upgrading and resource support, these problems seriously restricted the process of enterprise transformation and upgrading. SMEs suffer serious excess capacity, and the slowdown economy force market pressures, which make it urgent to accelerate the pace of transformation upgrade.

\section{Strategy of China's Small and Medium Enterprises out of Dilemma in the New Period}

Broaden Financing Channels. Firstly, develop local small and medium enterprise financial institutions. Local medium and small financial institutions can accurately understand the business situation of small and medium-sized enterprises, credit qualification and business prospects, which is an important financing channels for small and medium enterprises. Secondly, simplify loan procedures, strengthen regulation, supervision and services for the small loans, private lending other aspects, relax the restrictions on the main body of financial institutions, and guide all kinds of financial institutions to set up franchise institutions for Small and medium enterprise service and additional loans. Thirdly, innovate financing way. The small and medium-sized enterprise implement loan coinsurance, mutual insurance for corporate finance. In addition, it can also take the enterprise internal staff shares and raise funds for small and medium enterprise financing. Finally, for the public, semi public and for-profit small and medium enterprise services organizations do support policy research, strengthen the classification guidance, improve operability.

Cultivate Talent Team. First, actively organize personnel training, make full use of the advantages of colleges and universities, social training institutions and scientific research units, regularly organize seminars, training courses, conduct a more systematic training for small and medium enterprises. Second, introduce high-tech talent, update the talent management system, improve the quality of business managers and employees, and enhance the enterprise's market forecasts, corporate decision-making and management capabilities. Third, retain talent. To establish and improve employee's wages and benefits, labor protection and pension, industrial injury, unemployment, medical and other social security system.

Promote Technological Innovation. The government should play an active role in guiding, through technical project support, technical innovation and discount policy, promote SMEs to get a large-scale technical transformation. Meanwhile, the Government can cooperate with universities to establish research platform, enable SMEs to obtain technical support. In addition, through the establishment of a sound legal system, protect the interests of small and medium enterprises and promote technological innovation and development of SMEs .

Accelerate the Transformation and Upgrading. First, further increase the financing of small and medium enterprises to support efforts, to broaden the financing channels for small and medium enterprises, to provide financial support for the transformation and upgrading of small and medium enterprises. Second, to further improve the service system for small and medium enterprises, to provide a advice and services platform for enterprise transformation and upgrading, focusing on strengthening services for technology research and development, personnel training, skills training, management enhancing, system improvement and other aspects. Third, to increase financial support of entrepreneurial SMEs, and encourage small and medium enterprises to strengthen technology research and development, leading innovative SMEs to further increase investment in research and development, implement pre-tax deduction policy of income tax on R \& D expenses, take the road of new special expertise. Finally, strengthen the fair competition and intellectual property protection, to create a good external environment for the enterprise ${ }^{[4]}$.

\section{Conclusions}

Small and medium-sized enterprise is an important force in the national economy and social development. Its development is not only an important basis for the stable and rapid development of 
the national economy, but also affect the stability of people's livelihood and society. Based on the important role of small and medium-sized enterprises in China's economic sustainable development, we must constantly improve the environment of small and medium-sized enterprise development in the new period. In this period, the small and medium-sized enterprises in China are faced with the shortage of funds, lack of human resources, lack of innovation consciousness,difficult transformation and upgrading and other challenges, which seriously hinder the pace of small and medium enterprises,so it is needed to broaden the financing channels, cultivate the talent team, promote technological innovation, accelerate the transformation and upgrading to improve internal and external conditions.

\section{References}

[1] Fang LIU, The Development of Dmall and Medium Dized Dnterprises in China -- A Study on the Transformation and Upgrading of Dmall and Medium Sized Enterprises under the new situation J. Contemporary Economic Management, 2(2014)9-18(in Chinese).

[2] Li Peng LI, Qinxian BAI. Strategic Capabilities, Technological Innovation and the Development of Small and Medium Enterprises J. Economic Issues, 6(2014)83-88(in Chinese).

[3] Xueru XION, Zetian WANG. Research on the Transformation of the Development Mode of Small and Medium-sized Enterprises in Shenzhen, Hong Kong and Taiwan J. Economic System Reform, 3(2014)110-114(in Chinese).

[4] Jin BAI. Analysis of Sustainable Development of Small and Medium Enterprises J. Financial Accounting and Communication, 8(2014)69-70(in Chinese). 